Creative Commons User License: CC BY-NC-ND

Abstracted by: EBSCOhost, Electronic Journals Service (EJS), Google Scholar, Journal Seek, Scientific Commons,

Food and Agricultural Organization (FAO), CABI and Scopus
Journal of Agricultural Extension

Vol. 25 (3) July, 2021

ISSN(e): 24086851; ISSN(Print); 1119944X

http://journal.aesonnigeria.org

http://www.ajol.info/index.php/jae

Email: editorinchief@aesonnigeria.org

\title{
Women Farmers Perception of Information Dissemination Skills among Agricultural Extension Workers in North Eastern Nigeria
}

https://dx.doi.org/10.4314/jae.v25i3.6

\author{
Umar, Abdulmumini \\ Department of Agriculture Technology, Faculty of Agriculture, Universiti Putra Malaysia \\ (UPM), 43400 UPM Serdang, Selangor, Malaysia
}

Email: umwakill@gmail.com; Phone: +2348060643402

\section{Norsida, Man}

Department of Agriculture Technology, Faculty of Agriculture, Universiti Putra Malaysia

(UPM), 43400 UPM Serdang, Selangor, Malaysia

Email: norsida@upm.edu.my Corresponding Author; Phone: + 60-123993872

\section{Nitty, Hirawaty Kamarulzaman}

Department of Agribusiness and Bioresources Economy, Faculty of Agriculture, Universiti

Putra Malaysia (UPM), 43400 UPM Serdang, Selangor, Malaysia

Email: nitty@upm.edu.my; Phone: +60-148213722

\section{Nur, Bahiah Mohd Haris}

Department of Agriculture Technology, Faculty of Agriculture, Universiti Putra Malaysia (UPM), 43400 UPM Serdang, Selangor, Malaysia

Email: nurbahiah@upm.edu.my; Phone: +60-122859855

\begin{abstract}
This study examined the perception of rural women farmers on information dissemination skills of agricultural extension workers. Using multistage sampling procedure 378 respondents were randomly selected from the population of 6758 women farmers. Questionnaire was administered to the sampled farmers. Data were analysed using mean, and standard deviation. Findings reveals that women farmers participated moderately in agricultural practices with overall mean value of 2.65. Also, agricultural extension workers had a lower level of information dissemination skill in dealing with women farmers with overall mean value of 2.25. There is the need for training and retraining of extension workers to boost their skills for information delivery to women farmers. Extension programme for rural women should be designed to ensure extension workers are well informed and knowledgeable enough to work with them.
\end{abstract}

Keyword; Information dissemination, women farmers, agricultural extension workers

\section{Introduction}

Information is regarded as an important factor required in all aspect of agricultural production (Akinwale, 2020). Access to timely, relevant and reliable agricultural information is necessary for agricultural development (Zhang., Wang, \& Duan, 2016). Highly developed and organised flow of agricultural information is capable of 
Creative Commons User License: CC BY-NC-ND

Abstracted by: EBSCOhost, Electronic Journals Service (EJS), Google Scholar, Journal Seek, Scientific Commons,

Food and Agricultural Organization (FAO), CABI and Scopus
Journal of Agricultural Extension

Vol. 25 (3) July, 2021

ISSN(e): 24086851; ISSN(Print); 1119944X

http://journal.aesonnigeria.org

http://www.ajol.info/index.php/jae

Email: editorinchief@aesonnigeria.org

enhancing productivity and better market price for farmers, increase farmers knowledge and facilitate agricultural activities in rural areas (Msoffe \& Ngulube, 2016). However, many African countries do not have organised channels of disseminating relevant agricultural information and knowledge to farmers (Aldosari., Al Shunaifi, Ullah, Muddassir \& Noor, 2019). The need to determine the information dissimination skills of agricultural extension workers (AEWs) in the transmission of relevant information and knowledge of agricultural practices in rural areas become necessary

Agricultural information dissemination has been found to increase farmers' access to agricultural knowledge and ideas which assist them in decisions making regarding farming activities. (Msoffe \& Ngulube, 2016; Ranii, Metha, Rani, 2019 \& Damba et al., 2020). Agricultural information has significant impact on economic growth and development of many nations (Zhang et al., 2016). There are variety of factors that prevent rural farmers from accessing to agricultural information and knowledge in good time which need to be investigated (Nwafor,Ogundeji \& van der Westhuizen, 2020).

Obtaining high quality agricultural output is related to information availability to farmers (Msoffe \& Ngulube, 2016; Aldosari., et al, 2019 \& Global Agriculture, 2020) and effective information transmission accelerate productivity (Buehren, Goldstein, Molina, \& Vaillan 2019) and encourage farmers participation (Danso-Abbeam, Ehiakpor \& Aidoo, 2018). Information dissemination through extension services and organization provide direction for rural farmers to make better decision (Gebreegziabher \& Mezgebo, 2020; Okwu \& Umoru, 2019). Access to Information by farmers in rural areas of developing nations is provided through variety of means including mass media and other local facilities used by extension officers (Msoffe \& Ngulube, 2016; Relebohile \& Keregero, 2019).

Agricultural extension workers have a greater role to play in bridging the information gap between the information source (research institutions) and women farmers. The evidence of low farm output and poor quality of agricultural yield among women farmers is attributed to limited access to information and knowledge of agricultural practices (Buehren, Goldstein, Molina, \& Vaillant, 2019) Similarly, inadequate information and poor allocation of agricultural resources among women in rural communities resulted in lower level of agricultural productivity (Zhang et al., 2016; Uduji, Okolo-Obasi \& Asongu, 2019).

There are factors that create an information gap between extension workers and women farmers which affect farmers participation in farm activities (Takahashi, Muraoka \& Otsuka, 2020). Culture that prevented women farmers to interact with extension agent (Ali, 2020). The women farmers depend on their husbands and fellow women to provide the needed information which are mostly inadequate and cannot meet their need (Buehren, Goldstein, Molina \& Vaillant, 2019). Information must be made available and easily accessible by extension workers for farmers to assimilate, digest and made easily available and utilized (Anaglo, Manteaw \& 
Creative Commons User License: CC BY-NC-ND

Abstracted by: EBSCOhost, Electronic Journals Service (EJS),

Google Scholar, Journal Seek, Scientific Commons,

Food and Agricultural Organization (FAO), CABI and Scopus
Journal of Agricultural Extension

Vol. 25 (3) July, 2021

ISSN(e): 24086851; ISSN(Print); 1119944X

http://journal.aesonnigeria.org

http://www.ajol.info/index.php/jae

Email: editorinchief@aesonnigeria.org

Kwapong, 2020). Therefore, transmission of information to rural farmers require certain skills which need to be assess regularly for efficient performance (Msoffe \& Ngulube, 2016). This study provided information on AEWs skills in the transmission of knowledge to women farmers which would provide a guide in policy and decision making regarding the competency of AEWs in dealing with women farmers

Extension workers must be competent enough to use the various facilities to ensure proper information dissemination for women farmers who are mostly uneducated and poor (Norton, \& Alwang, 2020). For agricultural extension service to function effectively in rural areas, it must strengthen the relationship and contact between extension workers and women farmers through different method (Norton \& Alwang, 2020) Professional extension workers should also be involved and regularly examined and provided with adequate training in extension method as well as communication skills in dealing with women farmers (Takahashi, et all, 2020; Cascio, \& Montealegre, 2016)).

Information dissemination skills of AEWs has been found to reduce rural poverty, increase farming output, and provide better household income (Damba, Kodwo Ansah, Donkoh, Alhassan, Mullins, Yussif, Taylor, Tetteh \& Appiah-Twumasi, 2020). Farmers need information that enhance productivity and enable them meet market target, increase profit and take decision in good time. (Norton \& Alwang, 2020). Effective dissemination of agricultural information and knowledge by extension workers to women farmers increase income level, thereby enhance their quality of life (Kyaw, Ahn, \& Lee, 2018). An empirical study revealed significant relationship between information dissemination for farmers and agricultural productivity (Funom \& Soyemi, 2020). Similarly, availability and utilization of agricultural information improve socio- economic wellbeing of farmers (Funom \& Soyemi, 2020). Information access improve farmers' quality of life as the livelihood of millions of farmers is supported by good information for food production (Damba et al., 2020; Drafor, 2016).

The conventional methods of information dissemination adopted by extension workers especially in developing nations do not adequately provide the required information in good time for rural farmers. Such methods include farm lecture, farm visit, schedule meeting or home visits and individual contact (Akinwale, 2020; Funom, \& Soyemi, 2020). Other methods of information dissemination in rural areas of developing countries include the use of media including radio, video, television, pictures, print materials, drama, folklore and exhibitions (Msoffe \& Ngulube, 2016). This study investigated the skills of AEWs in disseminating information to women farmers. Specifically, the study determined:

1. the level of rural women farmers participation in agricultural practices in north eastern Nigeria

2. the level of information dissemination skills of agricultural extension workers in north eastern Nigeria 
Creative Commons User License: CC BY-NC-ND

Abstracted by: EBSCOhost, Electronic Journals Service (EJS),

Google Scholar, Journal Seek, Scientific Commons,

Food and Agricultural Organization (FAO), CABI and Scopus
Journal of Agricultural Extension

Vol. 25 (3) July, 2021

ISSN(e): 24086851; ISSN(Print); 1119944X

http://journal.aesonnigeria.org

http://www.ajol.info/index.php/jae

Email: editorinchief@aesonnigeria.org

\section{Methodology}

The area of study was North Eastern Nigeria (latitude $10^{\circ} 00^{\prime}-11^{\circ} 00^{\prime} \mathrm{N}$ and longitude $11^{\circ} 00^{\prime}-12^{\circ} 00^{\prime} \mathrm{E}$ ). The area consists of six states namely; Gombe, Adamawa, Yobe, Taraba, Bauchi and Borno State. The population of the study was 6758 registered women farmers in 24 rural communities in north eastern Nigeria (Cooperative Financing Agency, 2020). A sample size of 378 women farmers was randomly selected from the population using multistage sampling procedure. Purposive sampling of two local government areas from each state of North eastern Nigeria was carried out in the first stage. This was based on their status of being rural. In stage two, simple random sampling techniques was used for the selection of two rural communities from each of the local government. areas. In stage three, proportionate sampling was used for the selection of women farmers from each community. Data was collected from the women farmers about their perception on information dissemination skills of extension workers and level of participation of women in agricultural practices

The instrument used for data collection was a structured questionnaire. The questionnaire was validated and pilot tested. Reliability coefficient of 0.87 was obtained. The data was also subjected to exploratory data analysis using SPSS to check for normality, multicollinearity, outliers as well as missing data before the final data analysis. The final data analysis was conducted using descriptive (mean) and inferential (correlation) statistics. The decision rule on the levels of the participation (dependant variable) and information dissemination skills (independent variable) was determined by three categories of mean scores (Low 1.00-2.33, Moderate 2.34-3.67, and High 3.68-5.00). The mean difference was determined by dividing the overall mean score of 5.00 by 3 .

\section{Results and Discussion}

\section{Women Farmers Participation in Agricultural Practices}

Table 1, reveals that, from the perspectives of women farmers, there is a high level of participation of women in crop production $(\bar{x}=3.7)$, moderate participation in

livestock ( $\bar{x}=2.9$ ), horticulture ( $\bar{x}=2.5$ ) and poultry production ( $\bar{x}=2.5$ ), and low level of participation in fish production practices $(\bar{x}=1.68)$. Table 1 also reveals that

women farmers participate moderately in agricultural practices with overall mean value of 2.65. This indicate that women participate in crop production, animal production, horticulture and poultry production with little participation in fish production. This finding is in line with that of: Aldosari., et al, (2019) and Buehren, et al, (2019) that women are making significant impact on economic wellbeing of individuals due to their participation in agriculture. Similarly, Global Agriculture (2020) reported that women participate in farm labor which accounts for about 43 percent in Latin America ,20 percent in Asia and 50 percent in Africa. 
Creative Commons User License: CC BY-NC-ND

Abstracted by: EBSCOhost, Electronic Journals Service (EJS), Google Scholar, Journal Seek, Scientific Commons,

Food and Agricultural Organization (FAO), CABI and Scopus
Journal of Agricultural Extension

Vol. 25 (3) July, 2021

ISSN(e): 24086851; ISSN(Print); 1119944X

http://journal.aesonnigeria.org

http://www.ajol.info/index.php/jae

Email: editorinchief@aesonnigeria.org

The lower level of participation in fish production in the study area indicate the limited level of knowledge and information received by women farmers on fish farming and management. Meanwhile moderate participation in livestock, horticulture and poultry indicated an average information and knowledge received by women farmers.

Table I: Level of women farmers participation in agricultural practices

\begin{tabular}{|c|c|c|c|}
\hline Items & Mean & Mean Avarage & SD \\
\hline Crop production & & 3.69 & 0.40 \\
\hline Weeding & 3.40 & & \\
\hline Thinning & 3.53 & & \\
\hline Harvesting & 3.73 & & \\
\hline Processing & 4.08 & & \\
\hline $\begin{array}{l}\text { Livestock management and } \\
\text { production practices }\end{array}$ & & 2.92 & 0.46 \\
\hline Grazing & 3.44 & & \\
\hline Feeding & 3.70 & & \\
\hline Castration & 1.62 & & \\
\hline Watering & 3.12 & & \\
\hline Housing management & 2.42 & & \\
\hline Disinfection & 2.31 & & \\
\hline Quarantine & 3.60 & & \\
\hline Weaning & 3.14 & & \\
\hline $\begin{array}{l}\text { Horticultural/ fruit and vegetable } \\
\text { production practice }\end{array}$ & & 2.46 & 0.77 \\
\hline Raising seedlings & 3.30 & & \\
\hline Transplanting & 3.02 & & \\
\hline Mulching & 3.20 & & \\
\hline Pruning & 2.48 & & \\
\hline Grafting & 2.06 & & \\
\hline Budding & 1.04 & & \\
\hline Layering & 1.05 & & \\
\hline Planting & 3.40 & & \\
\hline Fruit collection & 3.05 & & \\
\hline Preparing nursery bed & 2.04 & & \\
\hline Poultry production practices & & 2.48 & 0.85 \\
\hline Housing management & 3.08 & & \\
\hline Feeding & 3.46 & & \\
\hline Watering & 3.50 & & \\
\hline Brooding & 2.26 & & \\
\hline Egg collection & 2.00 & & \\
\hline Record keeping & 1.06 & & \\
\hline Management of health condition & 2.02 & & \\
\hline Fish production practices & & 1.68 & 0.88 \\
\hline Fish pond management & 1.40 & & \\
\hline Water control & 1.10 & & \\
\hline Stacking finger lines & 1.08 & & \\
\hline Feeding & 3.11 & & \\
\hline Record keeping & 1.03 & & \\
\hline Fish harvesting & 2.36 & & \\
\hline OVERAL MEAN & & 2.65 & 0.67 \\
\hline
\end{tabular}

Source; Field survey 2020

\section{Information Dissemination skills of Extension workers}

Table 2 reveals that, from the perspectives of women farmers, extension workers had a moderate skill in the use of media system for disseminating information to women farmers $(\bar{x}=3.5)$, they also had a lower skill in the consideration of social system $(\bar{x}=1.8)$ and lower skills in the consideration of personal environment $(\bar{x}=$ 2.3). Table 2 also reveals the perception of women farmers that, extension workers had lower information dissemination skill in dealing with women with overall mean 
Creative Commons User License: CC BY-NC-ND

Abstracted by: EBSCOhost, Electronic Journals Service (EJS), Google Scholar, Journal Seek, Scientific Commons,

Food and Agricultural Organization (FAO), CABI and Scopus
Journal of Agricultural Extension

Vol. 25 (3) July, 2021

ISSN(e): 24086851; ISSN(Print); 1119944X

http://journal.aesonnigeria.org

http://www.ajol.info/index.php/jae

Email: editorinchief@aesonnigeria.org

value of 2.25. This means that extension workers do not adequately consider social system and environment in dissemination of information for women farmers. This finding is in line with that of Aldosari et al., (2019) that there is need for training to equip extension workers with necessary competencies on emerging technologies on information dissemination method, to be able to impact the required knowledge. Similarly, Danso-Abbeam et al, 2018) reported that inadequate information and poor allocation of agricultural resources among women in rural communities resulted in lower level of agricultural productivity. This is also supported by Msoffe \& Ngulube, (2016) that obtaining high quality agricultural output is related to information availability for farmers. Effective information transmission accelerate productivity and encourage farmers participation (Danso-Abbeam et al., 2018).

Table 2 with overall mean of 2.25 indicate a lower level of information dissemination skills by extension workers for women farmers, this may be responsible for limited access to information and knowledge of agricultural practices as supported by (Buehren et al, 2019). The evidence of low farm output and poor quality of agricultural yield among women farmers is attributed to lack of information and knowledge of agricultural practices

\section{Table 2: Level of information dissemination skills of AEWs}

\begin{tabular}{|c|c|c|c|}
\hline Items & Mean & Mean Avarage & SD \\
\hline Media System & & 3.47 & 0.58 \\
\hline $\begin{array}{l}\text { Extension workers are effective in the use of mass media for } \\
\text { dissiminating information to rural women farmers }\end{array}$ & 3.80 & & \\
\hline $\begin{array}{l}\text { Extension workers are effective in the use of ICT facilities for } \\
\text { disseminating information to rural women farmers }\end{array}$ & 3.50 & & \\
\hline $\begin{array}{l}\text { Extension workers are effective in the use of telecommunication } \\
\text { system for rural women farmers }\end{array}$ & 3.10 & & \\
\hline Social System & & 1.79 & 0.62 \\
\hline $\begin{array}{l}\text { Extension workers always consider the knowledge level of rural } \\
\text { women farmers in information delivery }\end{array}$ & 1.32 & & \\
\hline $\begin{array}{l}\text { Extension workers respect the local language of rural women farmers } \\
\text { in dissemination of Information }\end{array}$ & 2.33 & & \\
\hline $\begin{array}{l}\text { Extension workers consider the culture of rural women in information } \\
\text { delivery }\end{array}$ & 1.10 & & \\
\hline $\begin{array}{l}\text { Extension workers respect the tradition of rural women farmers in } \\
\text { dissemination of information to them }\end{array}$ & 1.33 & & \\
\hline $\begin{array}{l}\text { Extension workers respect the lifestyle of rural women farmers in } \\
\text { information dissemination }\end{array}$ & 2.43 & & \\
\hline $\begin{array}{l}\text { Extension workers always consider the religion of rural women } \\
\text { farmers in disseminating information }\end{array}$ & 2.20 & & \\
\hline Personal Environment & & 1.48 & 0.68 \\
\hline $\begin{array}{l}\text { Extension workers properly disseminate information to rural women } \\
\text { farmers from their home environment }\end{array}$ & 1.20 & & \\
\hline $\begin{array}{l}\text { Extension workers perfectly disseminate information to rural women } \\
\text { farmers from their office environment }\end{array}$ & 1.50 & & \\
\hline $\begin{array}{l}\text { Extension workers disseminate information to rural women farmers at } \\
\text { rural environment }\end{array}$ & 2.02 & & \\
\hline $\begin{array}{l}\text { Extension workers disseminate information accurately to rural women } \\
\text { farmers at their leisure environment }\end{array}$ & 1.22 & & \\
\hline OVERAL MEAN & & 2.25 & 0.62 \\
\hline
\end{tabular}

Source; Field survey 2020 
Creative Commons User License: CC BY-NC-ND

Abstracted by: EBSCOhost, Electronic Journals Service (EJS), Google Scholar, Journal Seek, Scientific Commons,

Food and Agricultural Organization (FAO), CABI and Scopus
Journal of Agricultural Extension

Vol. 25 (3) July, 2021

ISSN(e): 24086851; ISSN(Print); 1119944X

http://journal.aesonnigeria.org

http://www.ajol.info/index.php/jae

Email: editorinchief@aesonnigeria.org

\section{Conclusion and Recommendation}

Lack of access to agricultural information and knowledge were the main challenges affecting RWFs participation in agricultural practices. Lower level of information dissemination skill, lack of diversification in the selection of appropriate method, poor consideration of the women farmers needs as well as environment significantly affect participation of RWFs.

The need for training and retraining of extension workers to boost their information dissemination skills to suit the need of rural women become necessary. The status of being women should be considered in designing any extension programme relating to information dissemination so as to effectively impact and transmit the needed idea, knowledge and skills. Similarly, extension programme and agencies should strategize and provide alternative means of reaching women farmers especially in rural areas where internet and other ICT facilities are not available. Preferably the use of conventional method of extension despite its disadvantages of being more time consuming and expensive. Introduction of ICT may be gradual and only where the facilities are available.

\section{References}

Akinwale, J., (2020). Analysis of Utilization of Mobile Phones in Agricultural Information Dissemination Among Maize Farmers in Ondo State, Nigeria. Researchgate.Net, 15(2), 39-49.

Aldosari, F., Al Shunaifi, M. S., Ullah, M. A., Muddassir, M., \& Noor, M. A. (2019). Farmers' perceptions regarding the use of Information and Communication Technology (ICT) in Khyber Pakhtunkhwa, Northern Pakistan. Journal of the Saudi Society of Agricultural Sciences, 18(2), 211-217. https://doi.org/10.1016/j.jssas.2017.05.004

Ali, N. S. (2020). Study of gender and its importance on agricultural extension work. Plant Archives, 20, 912-917.

Anaglo, J. N., Manteaw, S. A., \& Kwapong, N. A. (2020). Influence of Agricultural Information Sources on the Practices and Livelihood Outcome of Cassava Farmers in Eastern Region of Ghana. In Redefining Research for Sustainable Development and Livelihoods in Nigeria. Proceedings of the 6th National symposium of the Sustainable Livelihoods and Development Network for Africa Held at the Virginrose Resort, Victoria Island, Lagos, Nigeria April 6th-9th (pp. 16-25)

Buehren, N., Goldstein, M., Molina, E., \& Vaillant, J. (2019). The impact of strengthening agricultural extension services on women farmers: Evidence from Ethiopia. Agricultural Economics (United Kingdom), 50(4), 407-419. https://doi.org/10.1111/agec.12499

Cascio, W. F., \& Montealegre, R. (2016). How Technology Is Changing Work and Organizations. Annual Review of Organizational Psychology and Organizational Behavior, 3, 349-375. https://doi.org/10.1146/annurev-orgpsych-041015-062352

Damba, O. T., Kodwo Ansah, I. G., Donkoh, S. A., Alhassan, A., Mullins, G. R., Yussif, K., Taylor, M. S., Tetteh, B. K., \& Appiah-Twumasi, M. (2020). Effects of technology dissemination approaches on agricultural technology uptake and utilization in Northern 
Creative Commons User License: CC BY-NC-ND

Abstracted by: EBSCOhost, Electronic Journals Service (EJS), Google Scholar, Journal Seek, Scientific Commons,

Food and Agricultural Organization (FAO), CABI and Scopus
Journal of Agricultural Extension

Vol. 25 (3) July, 2021

ISSN(e): 24086851; ISSN(Print); 1119944X

http://journal.aesonnigeria.org

http://www.ajol.info/index.php/jae

Email: editorinchief@aesonnigeria.org

Ghana. Technology in Society, 62, 101-294.

https://doi.org/10.1016/j.techsoc.2020.101294

Danso-Abbeam, G., Ehiakpor, D. S., \& Aidoo, R. (2018). Agricultural extension and its effects on farm productivity and income: Insight from Northern Ghana. Agriculture and Food Security, 7(1), 1-10. https://doi.org/10.1186/s40066-018-0225-x

Dhehibi, B., Rudiger, U., Moyo, H. P., \& Dhraief, M. Z. (2020). Agricultural technology transfer preferences of smallholder farmers in Tunisia's arid regions. Sustainability (Switzerland), 12(1), 2-18. https://doi.org/10.3390/SU12010421

Drafor, I. (2016). Access to Information for Farm-Level Decision-Making. Journal of Agricultural and Food Information, 17(4), 230-245. https://doi.org/10.1080/10496505.2016.1213170

Funom, B. C., \& Soyemi, O. (2020). Agricultural Information Dissemination to Soybean Farmers in Niger State, Nigeria. Information Impact: Journal of Information and Knowledge Management, 10(2), 56. https://doi.org/10.4314/iijikm.v10i2.4

Gebreegziabher, K. T. \& Mezgebo G. K (2020) Smallholder Farmers Willingness to Pay for Privatized Agricultural Extension Services in Tigray National Regional State, Journal of Agricultural Extension 24 (4) 29-38

Global Agriculture (2020) Agriculture at a grassroots findings and recommendations. Retrieved 10 0ctober 2020 www.globalagriculture.org

Jha, S., Kaechele, H., Lana, M., Amjath-Babu, T. S., \& Sieber, S. (2020). Exploring farmers' perceptions of agricultural technologies: A case study from Tanzania. Sustainability (Switzerland), 12(3), 1-21. https://doi.org/10.3390/su12030998

Kyaw, N. N., Ahn, S., \& Lee, S. H. (2018). Analysis of the factors influencing market participation among smallholder rice farmers in Magway Region, Central Dry Zone of Myanmar. Sustainability (Switzerland), 10(12). https://doi.org/10.3390/su10124441

Lamontagne-Godwin, J., Cardey, S., Williams, F. E., Dorward, P. T., Aslam, N., \& Almas, M. (2019). Identifying gender-responsive approaches in rural advisory services that contribute to the institutionalisation of gender in Pakistan. Journal of Agricultural Education and Extension, 25(3), 267-288. https://doi.org/10.1080/1389224X.2019.1604392

Msoffe, G. E. P., \& Ngulube, P. (2016). Agricultural information dissemination in rural areas of developing countries: A proposed model for Tanzania. African Journal of Library Archives and Information Science, 26(2), 169-187.

Mulema, A. A., Jogo, W., Damtew, E., Mekonnen, K., \& Thorne, P. (2019). Women farmers' participation in the agricultural research process: implications for agricultural sustainability in Ethiopia. International Journal of Agricultural Sustainability, 17(2), 127145. https://doi.org/10.1080/14735903.2019.1569578

Norton, G. W., \& Alwang, J. (2020). Changes in Agricultural Extension and Implications for Farmer Adoption of New Practices. Applied Economic Perspectives and Policy, 42(1), 8-20. https://doi.org/10.1002/aepp.13008

Nwafor, C. U., Ogundeji, A. A., \& van der Westhuizen, C. (2020). Adoption of ICT-based 
Creative Commons User License: CC BY-NC-ND

Abstracted by: EBSCOhost, Electronic Journals Service (EJS), Google Scholar, Journal Seek, Scientific Commons,

Food and Agricultural Organization (FAO), CABI and Scopus
Journal of Agricultural Extension

Vol. 25 (3) July, 2021

ISSN(e): 24086851; ISSN(Print); 1119944X

http://journal.aesonnigeria.org

http://www.ajol.info/index.php/jae

Email: editorinchief@aesonnigeria.org

information sources and market participation among smallholder livestock farmers in South Africa. Agriculture (Switzerland), 10(2). https://doi.org/10.3390/agriculture10020044

Okwu, O. J., \& Umoru, B. I. (2019). A study of women farmers' agricultural information needs and accessibility: A case study of Apa local government area of Benue State, Nigeria. African Journal of Agricultural Research, 4(12), 1404-1409.

Ranii, M. Metha, M. Rani, K. (2019). Role of Rural Women in Agriculture. Pakistan Observer, 8(5), 205-207.

Relebohile, M., \& Keregero, K. J. B. (2019). Turning challenges into opportunity: Potential for adoption of e-extension in Lesotho. Journal of Agricultural Extension and Rural Development, 11(11), 184-191. https://doi.org/10.5897/jaerd2019.1040

Takahashi, K., Muraoka, R., \& Otsuka, K. (2020). Technology adoption, impact, and extension in developing countries' agriculture: A review of the recent literature. Agricultural Economics (United Kingdom), 51(1), 31-45. https://doi.org/10.1111/agec.12539

Uduji, J. I., Okolo-Obasi, E. N., \& Asongu, S. A. (2019). Corporate social responsibility and the role of rural women in sustainable agricultural development in sub-Saharan Africa: Evidence from the Niger Delta in Nigeria. Sustainable Development, 27(4), 692-703. https://doi.org/10.1002/sd.1933

Zhang, Y., Wang, L., \& Duan, Y. (2016). Agricultural information dissemination using ICTs: A review and analysis of information dissemination models in China. Information Processing in Agriculture, 3(1), 17-29. https://doi.org/10.1016/j.inpa.2015.11.002 